\title{
Sedimentation Processes and Useful Life of Mosul Dam Reservoir, Iraq
}

\author{
Issa E. Issa ${ }^{1,2}$, Nadhir Al-Ansari ${ }^{1}$, Govand Sherwany ${ }^{3}$, Sven Knutsson ${ }^{1}$ \\ ${ }^{1}$ Department of Civil, Environmental and Natural Resources Engineering, \\ Luleå University of Technology, Luleå, Sweden \\ ${ }^{2}$ Mosul University, Mosul, Iraq \\ ${ }^{3}$ Ministry of Higher Education and Scientific Research-KRG, Erbil, Iraq \\ Email: issa.elias@1tu.se,nadhir.alansari@1tu.se,sven.knutsson@1tu.se, govand.sherwani@mhe-krg.org
}

Received July 14, 2013; revised August 14, 2013; accepted August 21, 2013

Copyright (C) 2013 Issa E. Issa et al. This is an open access article distributed under the Creative Commons Attribution License, which permits unrestricted use, distribution, and reproduction in any medium, provided the original work is properly cited.

\begin{abstract}
The sedimentation process is the most important problems that affects directly the performance of reservoirs due to the reduction of the storage capacity and possible problems effecting the operation. Thus periodic assessment of the storage capacity and determining sediment deposition patterns is an important issue for operation and management of the reservoirs. In this study, bathymetric survey results and an analytical approach had been used to assess the characteristics of sedimentation and estimate the useful life of Mosul Reservoir. It is located on the Tigris River in the north of Iraq. The water surface area of its reservoir is $380 \mathrm{~km}^{2}$ with a designed storage capacity of $11.11 \mathrm{~km}^{3}$ at a maximum operating level (330 m a.s.l). The dam started operating in 1986. No detailed study was yet carried out to assess its reservoir. The present study indicated that the annual reduction rate in the dead and live storage capacities of the reservoir is $0.786 \%$ and $0.276 \%$ respectively. The observed results (bathymetric survey) and algebraic formula show approximately that the useful life of Mosul dam reservoir is about 125 years. Furthermore, the stage-storage capacity curves for the future periods (prediction curves) were established using bathymetric survey data.
\end{abstract}

Keywords: Bathymetric Survey; Mosul Dam; Reservoir Sedimentation Rate; Useful Life of Reservoir

\section{Introduction}

The decrease and scarcity of water resources in the Middle East due to increased demand have negative effects on the economic development and prosperity and thus affect political stability in the region [1-5]. Until 1970, Iraq was excluded from the neighboring countries that suffer from water scarcity due to the presence of the Tigris and Euphrates rivers despite the fact that in midseventies the Syrian cut the Euphrates water to impound some of their reservoirs [4]. The idea of construction of irrigation and flood control systems in Iraq were started in the first half of the twentieth century by the Board of Development created by the Kingdom of Iraq [4]. Primarily, it was to protect Baghdad, the capital, and other major cities from flooding. The 1970 to 1990 was the best period of development of Iraq's water systems. The process stopped in the 1990 due to the first Gulf War and UN sanctions. In 1977, the Turkish Government started to utilize the water of the Tigris and Euphrates Rivers through the South-eastern Anatolia Project (GAP). The project includes 22 multipurpose dams and 19 hydraulic power plants which are to irrigate $17,103 \mathrm{~km}^{2}$ of land with a total storage capacity of $100 \mathrm{~km}^{3}$ which is three times more than the overall capacity of Iraq and Syrian reservoirs $[4,5]$. Eight of these dams are to be constructed on the River Tigris, only three were built (two in 1997 and one in 1998). The irrigation projects in GAP will consume about $22.5 \mathrm{~km}^{3}$ of water per year after completion [3-5]. The total irrigated area in Iraq is estimated before the Iraq-Iran war and the second Gulf War to be around $40,000 \mathrm{~km}^{2}$ which decreased to $27,800 \mathrm{~km}^{2}$ after second Gulf War for the Euphrates-Tigris basin [3,4]. The reduction of flow in the Tigris and Euphrates Rivers in Iraq is considered to be a national crisis and will have severe negative consequences on health and on environmental, industrial and economic development $[4,5]$. In view of the above, the Iraqi Government should work to adopt effective procedures to overcome the water shortages. Among these procedures is the assessment the sedimentation rate in the reservoirs to determine actual storage capacities [4]. Mosul Reservoir is one of the 
strategic projects and its storage capacity needs to be evaluated. The reservoir was operated in 1986 and no detailed studies had yet been carried out to know the characteristics of sedimentation and determine its useful life.

In the present study, the two topographic maps of Mosul reservoir dated 1983 and 2011 in "Triangular Irregular Network" (TIN) format were used for the assessment of sedimentation rate and determining the reduction in the storage capacity for the live and dead storages as well as the whole Mosul reservoir during its operational period. The two surveys were used to determine the future shift in the stage-storage capacity curve of reservoir. Furthermore, the observed results and algebraic equation that were proposed by Gill [6] were used to determine the life span of Mosul reservoir.

\section{Study Area: Mosul Reservoir}

Mosul dam is one of the most important hydraulic structures in Iraq which has been built on the Tigris River, north of Iraq. The dam is an earth fill dam, $113 \mathrm{~m}$ high, $3650 \mathrm{~m}$ long with its spillway, located $60 \mathrm{~km}$ north west Mosul city at latitude $36^{\circ} 37^{\prime} 44^{\prime \prime} \mathrm{N}$ and longitude $42^{\circ} 49^{\prime} 23^{\prime \prime}$ E (Figure 1). The dam is multipurpose and in operation on July 7th, 1986 for irrigation, floods control and hydropower generation [7]. Mosul dam has a designed dead storage of $2.95 \mathrm{~km}^{3}$ and live storage of $8.16 \mathrm{~km}^{3}$; i.e. a total storage capacity of $11.11 \mathrm{~km}^{3}$. The maximum, full and dead storage levels of the reservoir are 335, 330 and $300 \mathrm{~m}$ a.s.l respectively. The shape of the reservoir is almost elongated and expands close to the dam site. Its length is about $45 \mathrm{~km}$ with width ranges from 2 to $14 \mathrm{~km}$ at the full level with $380 \mathrm{~km}^{2}$ waterspread area [7]. The main source of the water and sediment entering the reservoir flows from the River Tigris; Figure 2 shows the average monthly water inflow and outflow of the reservoir during 25 years of its operation. Ten seasonal valleys feed the reservoir, 7 from eastern side and 3 from the western side. These valleys contribute water and sediment during rain events that are less than $2 \%$ [8-11]. The catchment area of the River Tigris estimated above Mosul dam is about $54,900 \mathrm{~km}^{2}$ shared by Turkey, Syria and Iraq [12,13] and the catchment area of the valleys surrounding the reservoir is about 1375 $\mathrm{km}^{2}[14,10]$.

\section{Data Availability}

The hydrographic survey is a direct measurement and most accurate technique to determine the total volume of the sediment deposited in the reservoirs, sedimentation pattern and bottom profile in the reservoirs and lakes. The recent advances in Global Positioning System (GPS), echo sounding survey technique and computer programs caused a significant reduction in the efforts, time and cost of the collecting and analyzing survey data [15-17]. The 1986 and 2011 topographic maps in TIN format for Mosul reservoir area were used to evaluate the sedimentation rate. These maps were provided by Issa et al. [18] (Figure 3). The TIN maps were used to compute the storage capacity and water-spread area for live storage and dead storage zones using Arc/GIS software (Table 1). The reduction in storage capacity of the reservoir for the two surveys at different times represents the total volume of sediment accumulated in it [17]. Therefore, the above results were used to compute the volume of sediment deposited and the reduction in the water-spread area for the reservoir during 25 year of operating (Table 1).

\section{Results and Discussion}

The reservoirs are built to achieve certain purposes, e.g. irrigation, hydropower generation, flood control, navigational, urban water supply, etc. Reservoir sedimentation and consequent loss of storage capacity affects directly the future performance of reservoirs. Consequently, it is of prime importance to monitor the rate of sedimentation and the changes in the capacity of the reservoir. To achieve a real situation of the storage volume of water within Mosul reservoir it is important to know the following:

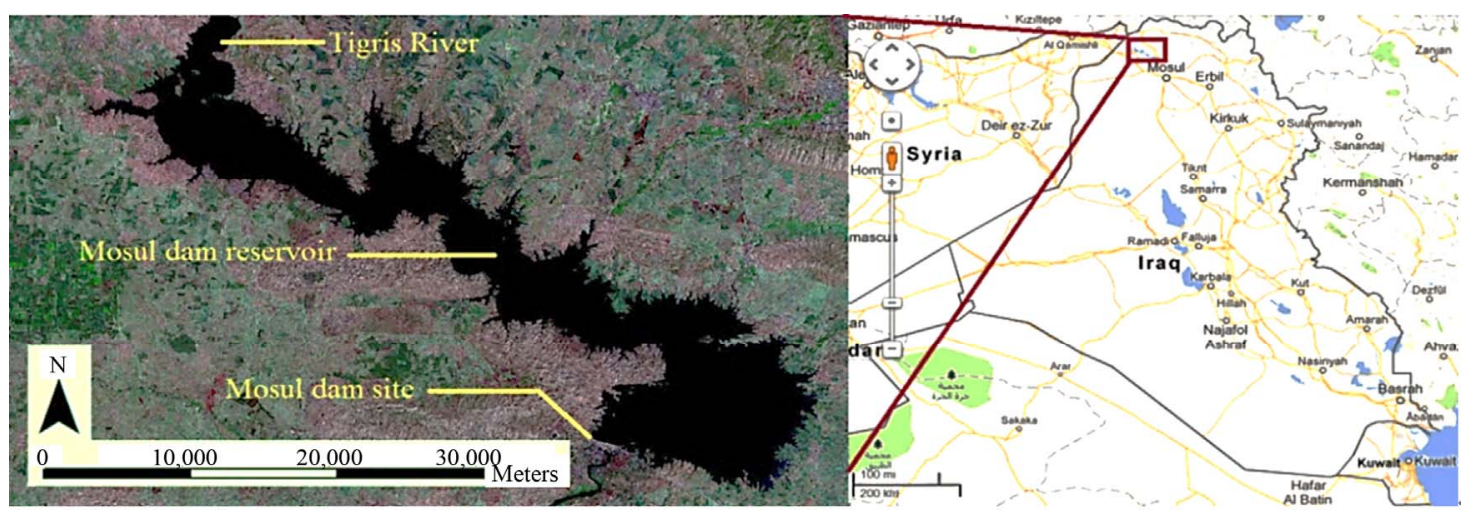

Figure 1. Location of Mosul Dam. 


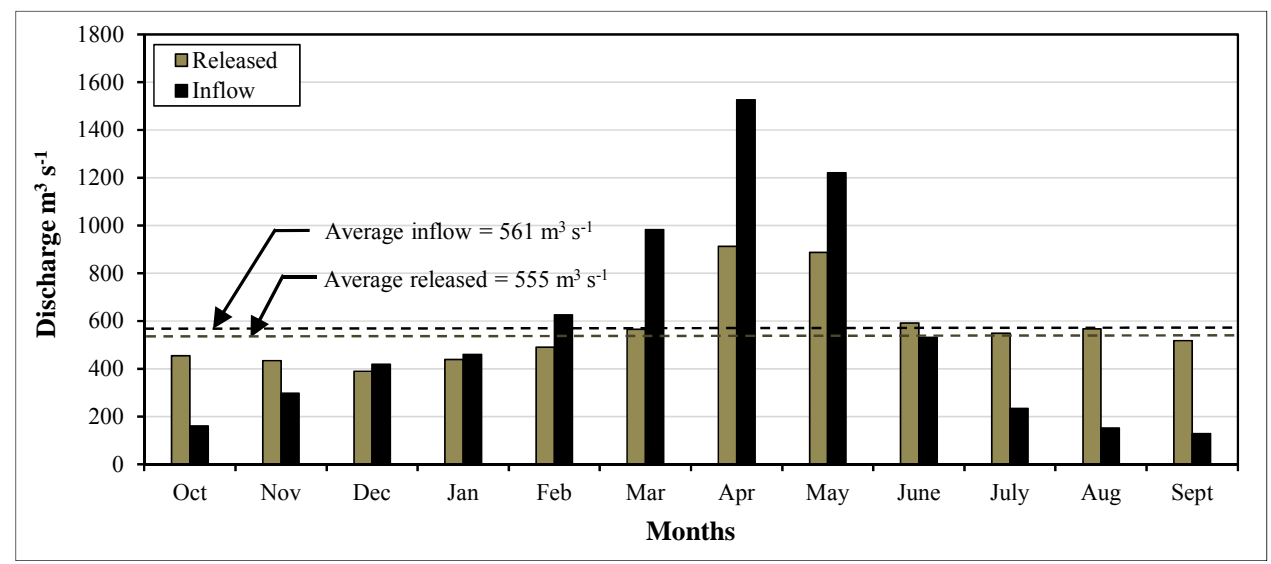

Figure 2. Monthly mean inflow and outflow of the Mosul reservoir for 1986-2011.

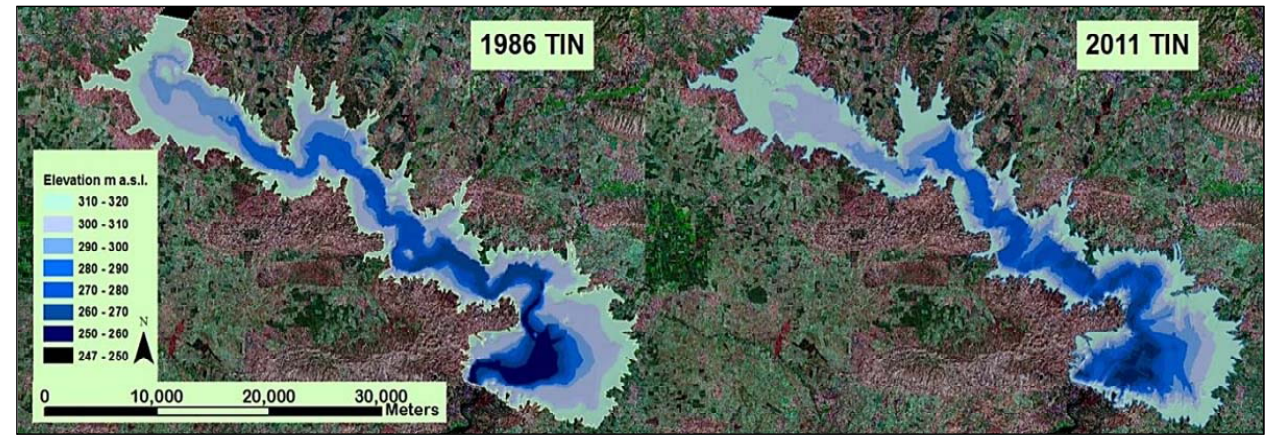

Figure 3. TIN maps of Mosul reservoir.

Table 1. Storage capacity and water-spread area of Mosul reservoir for two surveys.

\begin{tabular}{|c|c|c|c|c|c|c|c|c|}
\hline \multirow{2}{*}{$\begin{array}{c}\text { Storage } \\
\text { capacity in }\end{array}$} & \multicolumn{4}{|c|}{ Storage capacity (S.C) } & \multicolumn{4}{|c|}{ Water-spread area (W.S.A) } \\
\hline & $\begin{array}{c}\text { Survey } 1986 \\
\mathrm{~km}^{3}\end{array}$ & $\begin{array}{c}\text { Survey } 2011 \\
\mathrm{~km}^{3}\end{array}$ & $\begin{array}{c}\text { Difference in S.C } \\
\mathrm{km}^{3}\end{array}$ & $\begin{array}{c}\% \text { Reduction in } \\
\text { S.C }\end{array}$ & $\begin{array}{c}\text { Survey } 1986 \\
\mathrm{~km}^{2}\end{array}$ & $\begin{array}{c}\text { Survey } 2011 \\
\mathrm{~km}^{2}\end{array}$ & $\begin{array}{l}\text { Difference in } \\
\text { W.S.A km }\end{array}$ & $\begin{array}{c}\% \text { Reduction in } \\
\text { W.S.A }\end{array}$ \\
\hline Live zone & 8.16 & 7.597 & 0.563 & 6.9 & 380 & 363.5 & 16.5 & 4.34 \\
\hline Dead zone & 2.95 & 2.37 & 0.58 & 19.66 & 170 & 136.54 & 33.46 & 19.7 \\
\hline
\end{tabular}

\subsection{Useful Life of Reservoir}

The useful life or design life is a period that the sediment deposited does not affect the economic feasibility and sustainability of water resources demand. In general, useful life of the reservoir is the time period when the reservoirs depleted $50 \%$ of its storage capacity or the dead storage is completely filled with sediment $[6,19]$.

In the present study, the useful life for Mosul reservoir was computed using algebraic equations that were proposed by Gill [6]. The equations represent the relationship between initial storage capacity of reservoir, water and sediment inflow into the reservoir and specific weight of sediment deposited as shown in the following equations.

For coarse grained sediment

$$
\mathrm{T}_{\mathrm{L}}=\left[\frac{\gamma^{\prime} \times \mathrm{I}}{\mathrm{G}}\right]\left[\begin{array}{c}
0.4935 \frac{\mathrm{C}_{\mathrm{o}}}{\mathrm{I}}+0.3 \times 10^{-5} \\
\times \frac{\mathrm{I}}{\mathrm{C}_{\mathrm{o}}}+0.00436
\end{array}\right]
$$

Medium sediment

$$
\mathrm{T}_{\mathrm{L}}=\left[\frac{\gamma^{\prime} \times \mathrm{I}}{\mathrm{G}}\right]\left[0.008+0.51 \frac{\mathrm{C}_{\mathrm{o}}}{\mathrm{I}}\right]
$$

Fine sediment

$$
\mathrm{T}_{\mathrm{L}}=\left[\frac{\gamma^{\prime} \times \mathrm{I}}{\mathrm{G}}\right]\left[\begin{array}{c}
0.51328 \frac{\mathrm{C}_{\mathrm{o}}}{\mathrm{I}}-0.133 \times 10^{-3} \times \frac{\mathrm{I}}{\mathrm{C}_{\mathrm{o}}} \\
+0.153 \times 10^{-5} \times\left(\frac{\mathrm{I}}{\mathrm{C}_{\mathrm{o}}}\right)^{2}+0.018167
\end{array}\right]
$$


where, $C_{o}$ is the initial storage capacity of reservoir; $T_{L}$ is the useful life when the initial capacity reduce to half; $I$ is the annual water inflow; $G$ is the weight of annual sediment inflow; and $r^{\prime}$ is the specific weight of sediment deposited which was computed depending on the Lane and Koelzer empirical formula presented in 1953 [15,20].

The results of the above approach are presented in the Table 2. Furthermore, the bathymetric survey results (Table 1) were used for estimating the useful life based on the depleted dead storage and $50 \%$ loss of the initial storage capacity of the reservoir (Table 2). In such a case, the depositional conditions are assumed to be constant during the life of the dam. The observed results obtained from bathymetric survey and analytical approach were similar. Accordingly, it is possible to assume that the useful life for Mosul reservoir is approximately 125 year.

\subsection{Sedimentation Rate and Pattern}

According to the observed results (Table 1) the annual reduction rate in the storage capacity of the reservoir is
$45.72 \times 10^{6} \mathrm{~m}^{3} \cdot$ year $^{-1}$ which is divided into $23.2 \times 10^{6}$ and $22.52 \times 10^{6} \mathrm{~m}^{3} \cdot$ year $^{-1}$ for dead and live zones respectively. This implies that the annual loss of storage capacity within the dead and live zones is $0.787 \%$ and $0.276 \%$ respectively. Furthermore the annual loss in water-spread area of reservoir at dead storage elevation (300 m a.s.l) zone is $1.34 \mathrm{~km}^{2}$ (Figure 4). Figure 4 shows the maximum loss in water-spread area (water surface area) at the dead storage level in the northern part of the reservoir where the River Tigris enters the reservoir at this part. That means the most of sediment deposited in that area. This sequence is very logical in reservoirs [21].

The sedimentation in the reservoir caused a shift in the stage-storage capacity curve. The bathymetric survey results were used to compute the sedimentation rate for different water levels of reservoir that was used to predict the storage capacities at these levels for 50, 75, 100 and 125 years, all values are tabulated in Table 3.

The results in the above table were used to construct the stage-storage displacement curve during operation of the Mosul reservoir (Figure 5).

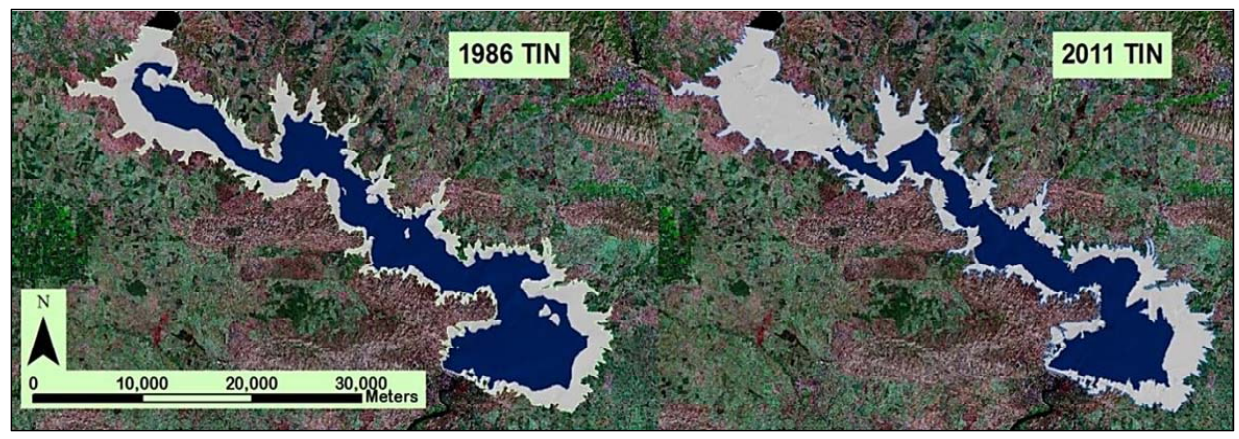

Figure 4. Boundary of water-spread area at dead storage elevation for two surveys calculated using Arc/GIS program.

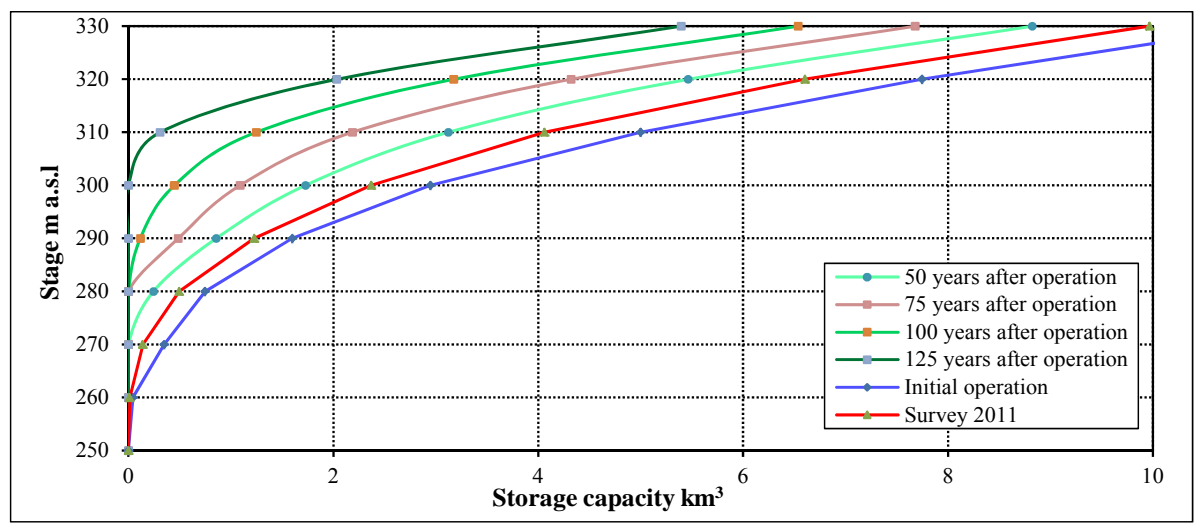

Figure 5. Stage-storage capacity curves for Mosul reservoir.

Table 2. Useful life of Mosul reservoir (year).

\begin{tabular}{ccccc}
\hline \multicolumn{2}{c}{ 2011 Bathymetric survey } & & Gill approach [6] \\
\hline Based on depleted dead storage & Based on 50\% reduction in S.C & Coarse Sediment & Medium Sediment & Fine sediment \\
127 & 121.5 & 122.5 & 127 & 132 \\
\hline
\end{tabular}


Table 3. Observed and predicted (expected) storage capacity of Mosul reservoir at different elevation.

\begin{tabular}{|c|c|c|c|c|c|c|c|}
\hline \multirow{2}{*}{ Water elevation } & \multirow{2}{*}{$\begin{array}{c}\text { Initial } \\
1986\end{array}$} & \multirow{2}{*}{$\begin{array}{c}\text { Bathymetric survey } \\
2011\end{array}$} & \multirow{2}{*}{$\begin{array}{c}\text { Sediment deposited during } 25 \\
\text { years of operation } \mathrm{Km}^{3}\end{array}$} & \multicolumn{4}{|c|}{ Storage capacity $\mathbf{k m}^{3}$ at years } \\
\hline & & & & 50 & 75 & 100 & 125 \\
\hline 250 & 0 & 0 & 0 & 0 & 0 & 0 & 0 \\
\hline 260 & 0.045 & 0.0137 & 0.0313 & 0 & 0 & 0 & 0 \\
\hline 270 & 0.35 & 0.141 & 0.209 & 0 & 0 & 0 & 0 \\
\hline 280 & 0.75 & 0.497 & 0.253 & 0.244 & 0 & 0 & 0 \\
\hline 290 & 1.6 & 1.229 & 0.371 & 0.858 & 0.487 & 0.116 & 0 \\
\hline 300 & 3.01 & 2.37 & 0.64 & 1.73 & 1.09 & 0.45 & 0 \\
\hline 310 & 5 & 4.062 & 0.938 & 3.124 & 2.186 & 1.248 & 0.498 \\
\hline 320 & 7.749 & 6.606 & 1.143 & 5.463 & 4.32 & 3.177 & 2.262 \\
\hline 330 & 11.11 & 9.967 & 1.143 & 8.824 & 7.681 & 6.538 & 5.623 \\
\hline
\end{tabular}

\section{Summary and Conclusion}

Reservoir sedimentation and consequent loss of storage capacity affect directly water availability and project operation. In the present study, two topographic plans in TIN format of 1986 and 2011 surveys were used for the assessment of reservoir sedimentation in live and dead storage zones. The results showed that the annual reduction in the dead and live storage capacities were $0.787 \%$ and $0.276 \%$ respectively. The water-spread area of the reservoir at dead storage level reduces annually by 1.34 $\mathrm{km}^{2}(0.79 \%)$. Furthermore, stage-storage capacity curves for future periods $50,75,100$ and 125 years were elaborated using the sedimentation rate on that elevation. The bathymetric results and analytical formulas gave almost similar results (125 year) for useful life storage of the reservoir.

\section{Acknowledgements}

The authors would like to express their thanks and gratitude to Luleå University of Technology, Sweden and the Swedish Hydropower Centre-SVC established by the Swedish Energy Agency, Elforsk and Svenska Kraftnät together with Luleå University of Technology, The Royal Institute of Technology, Chalmers University of Technology and Uppsala University. Their support is highly appreciated.

\section{REFERENCES}

[1] T. Naff, "Conflict and Water Use in the Middle East," In: R. Roger and P. Lydon, Eds., Water in the Arab World: Perspectives and Prognoses, Harvard University, Cambridge, 1993, pp. 253-284.

[2] N. A. Al-Ansari, "Water Resources in the Arab Countries: Problems and Possible Solutions," UNESCO International Conference on Water: A Looming Crisis, Paris, 1998, pp. $367-376$.

[3] D. Altinbilek, "Development and Management of the Euphrates-Tigris Basin," Water Resources Development, Vol. 20, No. 1, 2004, pp. 15-33. http://dx.doi.org/10.1080/07900620310001635584

[4] N. A. Al-Ansari and S. Knutsson, "Toward Prudent Management of Water Resources in Iraq," Journal of Advanced Science and Engineering Research, Vol. 1, No. 1, 2011, pp. 53-67.

[5] N. A. Al-Ansari, "Management of Water Resources in Iraq: Perspectives and Prognoses," Journal of Engineering, Vol. 5, 2013, pp. 667-684.

[6] M. A. Gill, "Sedimentation and Useful Life of Reservoirs," Journal of Hydrology, Vol. 44, No. 1-2, 1979, pp. 89-95. http://dx.doi.org/10.1016/0022-1694(79)90148-3

[7] Iraqi Ministry of Water Resources, "Water Resources, Mosul Dam,” 2012. http://en.mowr.gov.iq/

[8] M. Ezz-Aldeen, N. A. Al-Ansari and S. Knutsson, “Application of SWAT Model to Estimate the Runoff and Sediment Load from the Right Bank Valleys of Mosul Dam Reservoir," 6th International Conference on Scour and Erosion, Paris, 28-31 August 2012, pp. 1281-1287.

[9] M. Ezz-Aldeen, N. A. Al-Ansari and S. Knutsson, "Runoff and Sediment Load from the Right Bank Valleys of Mosul Dam Reservoir," Journal of Civil Engineering and Architecture, Vol. 6, No. 10, 2012, pp. 1414-1419.

[10] M. Ezz-Aldeen, N. A. Al-Ansari and S. Knutsson, "Sediment Delivery from Right Bank Valleys to Mosul Reservoir, Iraq," Journal of Ecology and Environmental Sciences, Vol. 3, No. 1, 2012, pp. 50-53.

[11] M. Ezz-Aldeen, N. A. Al-Ansari and S. Knutsson, “Application of Swat Model to Estimate the Sediment Load From the Left Bank of Mosul Dam," Journal Advanced Science and Engineering Research, Vol. 3, No. 1, 2013, pp. 47-61.

[12] Swiss Consultants, "Mosul Dam Project-Planning Report," State Organization of Dams, Republic of Iraq, Ministry of Irrigation, 1979, Vol. 1, pp. 1-41. 
[13] D. K. Saleh, "Stream Gage Descriptions and Stream Flow Statistics for Sites in the Tigris River and Euphrates River Basins, Iraq," US Department of the Interior, US Geological Survey, Data Series 540, 2010, pp. 1-154. http://pubs.usgs.gov/ds/540/pdf/ds540.pdf

[14] A. M. Muhammad and Y. T. Mohamed, "Estimating Water Yield from All Wadies That Flows to Eastern Bank of Mosul Dam Reservoir," Al-Rafidain Engineering Journal, Vol. 11, No. 2, 2005, pp. 46-56.

[15] G. L. Morris and J. Fan, "Reservoir Sedimentation Handbook, Design and Management of Dams, Reservoirs, and Watersheds for Sustainable Use," McGraw-Hill Book Co., New York, 1998.

[16] S. K. Jain and V. P. Singh, "Water Resources Systems Planning and Management," Elsevier Science B.V, Amsterdam, 2003.

[17] R. L. Ferrari and K. Collins, "Reservoir Survey and Data Analysis. Chapter 9. Erosion and Sedimentation Manual,"
Bureau of Reclamation, Sedimentation and River Hydraulics Group, Denver, 2006.

http://www.usbr.gov/pmts/sediment/kb/ErosionAndSedi mentation/

[18] I. E. Issa, N. A. Al-Ansari and S. Knutsson, "Sedimentation and New Operational Curve for Mosul Dam, Iraq," Hydrological Sciences Journal, Vol. 58, No. 7, 2013, pp. $1-11$.

[19] V. Garg and V. Jothiprakash, "Estimation of Useful Life of a Reservoir Using Sediment Trap Efficiency," Journal of Spatial Hydrology, Vol. 8, No. 2, 2008, pp. 1-14.

[20] G. W. Annandale, "Reservoir Sedimentation," Elsevier Science Publishers, New York, 1987.

[21] J. Fan and G. L. Morris, "Reservoir Sedimentation I: Delta and Density Current Deposits," Journal of Hydraulic Engineering, Vol. 118, No. 3, 1992, pp. 354-369. http://dx.doi.org/10.1061/(ASCE)0733-9429(1992)118:3( $\underline{354)}$ 